Religion und Gesellschaft 



\section{Religion und \\ Gesellschaft}

Sinnstiftungssysteme im Konflikt

Herausgegeben von

Friedrich Wilhelm Graf und Jens-Uwe Hartmann

\section{DE GRUYTER}


ISBN 978-3-11-058125-6

e-ISBN (PDF) 978-3-11-058261-1

e-ISBN (EPUB) 978-3-11-058132-4

Library of Congress Control Number: 2019946497

\section{Bibliografische Information der Deutschen Nationalbibliothek}

Die Deutsche Nationalbibliothek verzeichnet diese Publikation in der Deutschen Nationalbibliografie; detaillierte bibliografische Daten sind im Internet über http://dnb.dnb.de abrufbar.

(C) 2019 Walter de Gruyter GmbH, Berlin/Boston Druck und Bindung: $\mathrm{CPI}$ books $\mathrm{GmbH}$, Leck

Umschlagabbildung: jessicahyde / iStock / Getty Images Plus

www.degruyter.com 